\title{
Angiotensin II type 2 receptor signaling significantly attenuates growth of murine pancreatic carcinoma grafts in syngeneic mice
}

\author{
Chiyo Doi ${ }^{1}$, Noboru Egashira², Atsushi Kawabata', Dharmendra Kumar Maurya'', Naomi Ohta', \\ Deepthi Uppalapati', Rie Ayuzawa', Lara Pickel', Yuka Isayama', Deryl Troyer', \\ Susumu Takekoshi², Masaaki Tamura ${ }^{1 *}$
}

\begin{abstract}
Background: Pancreatic cancer is one of the most aggressive human malignancies, with a very poor prognosis. To evaluate the effect of angiotensin II (Ang II) type 2 receptor $\left(A T_{2}\right)$ expression in the host's body on the growth of pancreatic carcinoma, we have investigated the growth of mouse pancreatic ductal carcinoma grafts in syngeneic wild type and $\mathrm{AT}_{2}$ receptor-deficient $\left(\mathrm{AT}_{2}-\mathrm{KO}\right)$ mice.

Methods: The role of $\mathrm{AT}_{2}$ receptor-signaling in stromal cells on the growth of murine pancreatic carcinoma cells (PAN02) was studied using various in vitro and in vivo assays. In vivo cell proliferation, apoptosis, and vasculature in tumors were monitored by Ki-67 immunostaining, TUNEL assay, and von Willebrand factor immunostaining, respectively. In the co-culture study, cell proliferation was measured by MTT cell viability assay. All the data were analyzed using t-test and data were treated as significant when $p<0.05$.

Results: Our results show that the growth of subcutaneously transplanted syngeneic xenografts of PAN02 cells, mouse pancreatic ductal carcinoma cells derived from the C57/BL6 strain, was significantly faster in $A T_{2}-K O$ mice compared to control wild type mice. Immunohistochemical analysis of tumor tissue revealed significantly more Ki67 positive cells in xenografts grown in $\mathrm{AT}_{2}-\mathrm{KO}$ mice than in wild type mice. The index of apoptosis is slightly higher in wild type mice than in $\mathrm{AT}_{2}-\mathrm{KO}$ mice as evaluated by TUNEL assay. Tumor vasculature number was significantly higher in $\mathrm{AT}_{2}-\mathrm{KO}$ mice than in wild type mice. In vitro co-culture studies revealed that the growth of PAN02 cells was significantly decreased when grown with $\mathrm{AT}_{2}$ receptor gene transfected wild type and $\mathrm{AT}_{2}-\mathrm{KO}$ mouse-derived fibroblasts. Faster tumor growth in $\mathrm{AT}_{2}-\mathrm{KO}$ mice may be associated with higher VEGF production in stromal cells.

Conclusions: These results suggest that Ang II regulates the growth of pancreatic carcinoma cells through modulating functions of host stromal cells; Moreover, Ang $\| \mathrm{AT}_{2}$ receptor signaling is a negative regulator in the growth of pancreatic carcinoma cells. These findings indicate that the $\mathrm{AT}_{2}$ receptor in stromal fibroblasts is a potentially important target for chemotherapy for pancreatic cancer.
\end{abstract}

\section{Background}

Pancreatic cancer is one of the leading causes of cancer death in many countries, including the United States. Pancreatic ductal adenocarcinoma (PDAC) constitutes approximately $90 \%$ of all primary malignant tumors arising from the pancreatic gland. Of all

\footnotetext{
* Correspondence: mtamura@vet.ksu.edu

'Department of Anatomy \& Physiology, Kansas State University, College of Veterinary Medicine, Manhattan, KS 66506, USA
}

gastrointestinal malignancies, pancreatic adenocarcinoma is the second most common cause of death from cancer [1-3]. Pancreatic cancer is an aggressive malignant cancer with a high metastatic rate and is an almost uniformly lethal disease in humans [3-5]. Of affected patients, $60 \%$ have liver metastasis, malignant ascites, or other evidence of tumor spread at the time of diagnosis [6]. The 5-year survival rate in the United States is less than $5 \%[3]$.

\section{() Biomed Central}


The renin-angiotensin system is one of the phylogenetic hormone systems and plays a key role in the regulation of cardiovascular homeostasis, which maintains arterial blood pressure and fluid and electrolyte homeostasis [7,8]. Angiotensin II (Ang II), an octapeptide hormone, is the key effector in the renin-angiotensin system. Ang II has two well-defined receptors: Ang II type 1 $\left(\mathrm{AT}_{1}\right)$ and type $2\left(\mathrm{AT}_{2}\right)$ receptor [9]. The $\mathrm{AT}_{1}$ receptor is widely expressed in a variety of adult tissues. $\mathrm{AT}_{1}$ receptor-mediated signaling is responsible for most Ang IIdependent actions in cardiovascular and renal tissues. Responses of the $\mathrm{AT}_{1}$ receptor are typically associated with stimulation of growth factor receptors leading to cell growth, proliferation, cell migration, apoptosis, and gene expression $[10,11]$. These effects are executed through a heterotrimeric G protein-coupled receptor, which mediates Ang II transactivated epidermal growth factor (EGF)-induced activation of MEK (MAPK kinase 1) and ERK [12]. The $\mathrm{AT}_{2}$ receptor, the second major isoform of the Ang II receptor, is primarily expressed in the mesenchyme of the fetus and to a limited extent in adult tissues [13]. It is, however, inducible and functional under pathophysiologic conditions [14-17]. The $\mathrm{AT}_{2}$ receptor mediates signals that counteract the $\mathrm{AT}_{1}$ receptor-mediated biological actions [18-20]. In addition, the $\mathrm{AT}_{2}$ receptor is known to inhibit cell proliferation and stimulate apoptosis in cardiovascular and neuronal tissues in vitro [21]. However, the relationship between the $\mathrm{AT}_{2}$ receptor and cancer has yet to be clarified. Our previous studies revealed that chemical carcinogen-induced tumorigenesis in mouse colon [22] and lung [15] was significantly attenuated by $\mathrm{AT}_{2}$ receptor deficiency. Since $\mathrm{AT}_{2}$ receptor expression has been noted in various stromal fibroblasts $[23,24]$ and is inducible in the pancreas in pathological conditions [25], $\mathrm{AT}_{2}$ receptor deficiency may also influence pancreatic cancer growth. In addition, Ang II receptor antagonists and angiotensin I-converting enzyme inhibitors currently used for human clinical hypertension treatment attenuate growth of human cancer cells in experimental animals [26-30] and may reduce the risk of several human cancers[31]. This suggests that $\mathrm{AT}_{2}$ receptor expression potentially plays an important role in cancer.

In the present study, we subcutaneously inoculated pancreatic ductal carcinoma cells in syngeneic $\mathrm{AT}_{2}-\mathrm{KO}$ and wild type mice and examined tumor growth, cell proliferation, and apoptosis. In addition to the in vivo study, we also studied the effect of stromal fibroblasts, which were prepared from either $\mathrm{AT}_{2}-\mathrm{KO}$ or control wild type mice, on PAN02 cancer cell growth in vitro. These studies revealed that Ang II $\mathrm{AT}_{2}$ receptor signaling in stromal cells plays an important regulatory role in the growth of pancreatic carcinoma cells.

\section{Methods}

\section{Materials}

Ang II was purchased from Peninsula Laboratories Inc. (San Carlos, CA). The $\mathrm{AT}_{1}$ receptor blocker Losartan was a gift from Dr. Tadashi Inagami (Vanderbilt University Medical Center); the $\mathrm{AT}_{2}$ receptor blocker PD123319 was purchased from Sigma Chemical Co. (St. Louis, MO). Rabbit anti-human von Willebrand factor (vWF) and rat anti-mouse Ki-67 antibodies were purchased from DakoCytomation (Glostrup, Denmark). Rabbit anti-human vascular endothelial cell growth factor (VEGF) and rabbit anti-human GAPDH antibodies were from Santa Cruz Biotechnology, Inc. (Santa Cruz, CA). A biotin-conjugated secondary antibody was purchased from Jackson ImmunoResearch (West Grove, $\mathrm{PA})$. Avidin-biotin peroxidase complex (ABC) reagents was from Vector Laboratories (Burlingame, CA). Apop$\mathrm{Tag}^{\circledR}$ Plus Peroxidase In Situ Apoptosis Detection Kit was from Chemicon International, Inc. (Tokyo, Japan). Bio- $\alpha$ Rat biotin-conjugated secondary antibody was from Jackson ImmunoResearch, (West Grove, PA). A horseradish peroxidase-conjugated anti-rabbit IgG secondary antibody was from Amersham Biosciences (Piscataway, NJ). All other chemicals were of analytical grade.

\section{Cell culture}

The PAN02 murine pancreatic adenocarcinoma cell line was obtained from the National Cancer Institute and maintained in RPMI-1640 medium supplemented with $10 \%$ fetal bovine serum (FBS), $2 \mathrm{mM}$ L-glutamine, 100 $\mathrm{U} / \mathrm{ml}$ penicillin, and $100 \mu \mathrm{g} / \mathrm{ml}$ streptomycin.

Primary cultured mouse skin fibroblasts (MSFs) from wild type and $\mathrm{AT}_{2}-\mathrm{KO}$ mice were prepared from 24 to 48 hour old C57BL/6J mouse pups following an established method [14]. MSFs were cultured in DMEM/ Ham's F-12 medium (1:1) supplemented with $10 \%$ FBS, $100 \mathrm{U} / \mathrm{ml}$ penicillin, and $100 \mu \mathrm{g} / \mathrm{ml}$ streptomycin. All cells were incubated in $5 \% \mathrm{CO}_{2}$ humidified air at $37^{\circ} \mathrm{C}$.

\section{Animals and genotyping}

Hemizygous $\mathrm{AT}_{2}-\mathrm{KO}$ mutant (Agtr2-/y) mice were generated as described previously [15]. These mice were backcrossed with wild type C57BL/6J (The Jackson Laboratory, Bar Harbor, MA) for 17 generations such that the genetic background of the mice is susceptible to our pancreatic cancer syngeneic model. Wild type littermates served as controls. Genotypes were confirmed by the PCR method using extracted tail DNA. Briefly, published sequences $[19,32]$ were used to synthesize primers for the $\mathrm{AT}_{2}$ receptor (forward 5'-CACCAGCAGAAACATTAC-3' and reverse 5'AACACAGCTGTTGAATCC-3') and the neomycin resistance (Neo-r) gene product (forward 
5'-AGCCAACGCTATGTCCTGAT-3' and reverse 5'-AGACAATCGGCTGCTCTGAT-3'). Extracted tail DNA (10-20 ng) was amplified (35 cycles) at $95^{\circ} \mathrm{C}$ for 1 minute (denaturation), at $58^{\circ} \mathrm{C}$ for 1 minute (annealing), and at $72^{\circ} \mathrm{C}$ for 1 minute (elongation) with $0.5 \mathrm{nmol} / \mathrm{L}$ of each primer, 1.25 units DNA polymerase, and $0.2 \mathrm{mmol} / \mathrm{L}$ deoxynucleotide triphosphates in PCR buffer. PCR products of the $\mathrm{AT}_{2}$ receptor (478 bp) and Neo-r gene product (593 bp) were visualized by $1 \%$ agarose gel electrophoresis. $\mathrm{AT}_{2}(+)$ and Neo-r $(-), \mathrm{AT}_{2}(+)$ and Neo-r $(+)$, and $\mathrm{AT}_{2}(-)$ and Neo-r $(+)$ were assigned as wild type, heterozygote, and $\mathrm{AT}_{2}-\mathrm{KO}$, respectively. All animals were maintained in a humidity- and temperature-controlled room on 12-hour light/dark cycles. All procedures for handling animals were approved by the Institutional Committee for Animal Care and Use of Kansas State University.

\section{Pancreatic cancer syngeneic model}

Seven to nine week-old $\mathrm{AT}_{2}-\mathrm{KO} / \mathrm{C} 57 \mathrm{BL} / 6 \mathrm{~J}$ mice and wild-type littermates were anesthetized with isoflurane. Cells were trypsinized and washed with PBS. Five million cells in $200 \mu \mathrm{l}$ PBS were subcutaneously inoculated into each flank using a $1 \mathrm{ml}$ syringe with a $27 \mathrm{G}$ needle [16]. The tumor size was measured by caliper every three days and the volume was calculated using the formula (short diameter $)^{2} \times($ long diameter $) \times 0.5$ [17]

At the end of the experiments, the mice were sacrificed by cervical dislocation under anesthesia. The tumors were dissected and weighed. For histological assessment, the specimens were fixed in $10 \%$ formalin, embedded in paraffin, and sectioned for histopathological analysis.

\section{Immunohistochemical analysis}

Tissue sections of $4 \mu \mathrm{m}$ thickness were prepared for all staining. Slides were dewaxed and rehydrated before staining. The heat-induced antigen unmasking was performed in Citra Plus Solution, pH 6.0 (BioGenex, San Ramon, CA) for 5-10 minutes using an autoclave oven. Sections were then incubated with $0.3 \%$ hydrogen peroxide in methanol for 20 minutes to block endogenous peroxide activity. The dilution of antibodies for Ki-67, von Willebrand factor (vWF) and VEGF was 1:50, 1:100, and 1:50, respectively. Sections were incubated with the primary antibodies for 60 minutes at room temperature. In immunostaining for Ki-67, sections were incubated with biotin-conjugated secondary antibody (Jackson ImmunoResearch, West Grove, PA) followed by reaction with the avidin-biotin peroxidase complex (ABC) reagent (Vector Laboratories, Burlingame, $\mathrm{CA}$ ) for 30 minutes at room temperature. In immunostaining for vWF, an ABC kit (Vector Laboratories) was used. Peroxidase activity was visualized with 3,3 '-diaminobenzodine tetrahydrochloride (Sigma Chemical Co). Sections were lightly counterstained with Hematoxylin solution (Merck KGaA, Darmstadt, Germany).

\section{TUNEL assay}

To determine cell death, apoptotic cells in paraffin sections were detected by TUNEL (Terminal Deoxynucleotidyltransferase-Mediated dUTP Nick End Labeling) assay using the Apop Taq Plus Peroxidase In Situ Apoptosis Detection Kit (Millipore Corporation, Billerica, MA) according to the manufacturer's instructions. Sections were counterstained with Methyl green solution (Nacalai Tesque, Inc., Kyoto, Japan).

\section{Image analysis}

Ki-67 or TUNEL positive cell numbers and whole cell numbers (as background) in five randomly selected fields were counted by two independent observers. The VEGF positive cell area in five randomly selected fields was evaluated using $\mathrm{NIH}$ digital-image analyzing software, Image J 1.37v, (NIH, Bethesda, MD).

\section{Evaluation of the effect of angiotensin II and fibroblasts on the growth of PAN02 cells}

Primary cultured MSFs (100 cells/well, 96-well plate) from wild type or $\mathrm{AT}_{2}-\mathrm{KO}$ mice were incubated in serum-free medium in $5 \% \mathrm{CO}_{2}$ humidified air at $37^{\circ} \mathrm{C}$. Following 24 hours incubation, PAN02 cells (400 cells/ well) were added to the culture plate and co-cultured with the wild-type or $\mathrm{AT}_{2}-\mathrm{KO}$ MSFs in DMEM/Ham's F12 medium (1:1) containing 10\% FBS. One day after co-culture, the cells were treated with Ang II (10 nM) for 48 hours in the presence of the $\mathrm{AT}_{2}$ receptor-specific antagonist PD123319 $(10 \mu \mathrm{M})$. The degree of cell proliferation was evaluated by MTT assay. In brief, 10 $\mu \mathrm{l}$ MTT solution $(5 \mathrm{mg} / \mathrm{ml})$ was added to each well 4 hours prior the end of the incubation. Formazan crystals formed in the cells were dissolved by adding $100 \mu \mathrm{l}$ of MTT solvent $(0.01 \mathrm{~N} \mathrm{HCl}$ in $10 \% \mathrm{SDS})$. The absorbance was measured at $550 \mathrm{~nm}$ by spectrometer 24 hours after incubation at $37^{\circ} \mathrm{C}$ with the MTT solvent.

\section{Evaluation of the effect of $\mathrm{AT}_{2}$ receptor over-expression in fibroblasts on co-cultured PAN02 cell growth}

MSFs from wild type or $\mathrm{AT}_{2}-\mathrm{KO}$ mice were seeded in T25 flasks. After cell attachment, the medium was changed to serum-free DMEM. After three hours in the serum-free medium, the medium was changed to $875 \mu \mathrm{l}$ DMEM containing 5\% FBS and either adenoviral $\mathrm{AT}_{2}$ receptor $\left(\mathrm{Ad}-\mathrm{AT}_{2}, 25 \mathrm{MOI}\right.$ ) or adenoviral Lac $\mathrm{Z}$ (AdLac Z, $25 \mathrm{MOI})$. The cells were incubated in $5 \% \mathrm{CO}_{2}$ at $37^{\circ} \mathrm{C}$; the flasks were rocked every 15 minutes for 3 hours. After incubation with the vectors, DMEM/Ham's F12 (1:1) containing 10\% FBS was added and the cells 
were further incubated for an additional 24 hours at $37^{\circ} \mathrm{C}$ in $5 \% \mathrm{CO}_{2}$. Both untransfected and transfected MSFs were co-cultured with PAN02 cells (400 cells/ well) as described above. The extent of cell proliferation was evaluated by MTT assay.

\section{Gene expression analysis using real-time PCR}

Total RNA was extracted from cells using TRIzol reagent (Invitrogen). Genomic and complementary DNA was removed using RQ1 RNase-free DNase (Promega, Madison, WI) according to the manufacturer's instructions. Real-time PCR was carried out using an iScript One-Step RT-PCR Kit with SYBR Green (Bio-Rad, Hercules, CA), and the reactions were conducted on the real-time PCR detection system iCycler (Bio-Rad). The results were quantified as $C_{t}$ values, where $C_{t}$ is defined as the threshold cycle of PCR at which the amplified product is first detected and signifies relative gene expression (the ratio of target/control). The $\mathrm{AT}_{2}$ primers were 5'-AGC CAA GGC CAG ATT GAA GA-3' (forward) and 5'-GCC ACC AGC AGA AAC ATT ACC-3' (reverse), the AT1 primers were 5'-GGC AGC ATC GGA CTA AAT GG-3' (forward) and 5'-CCA GCT CCT GAC TTG TCC TTG-3' (reverse), and the 18S ribosome RNA primers were 5'-TCG CTC CAC CAA CTA AGA AC-3' (forward) and 5'-GAG GTT CGA AGA CGA TCA GA-3' (reverse).

\section{Western blot analysis}

Total cellular protein was prepared according to our routinely used protocol [33]. The membrane was incubated with the antibody against VEGF at a 1:250 dilution in TBST with $0.1 \%$ nonfat dry milk for $1 \mathrm{hr}$ at room temperature. Then, the membrane was incubated with a horseradish peroxidase-conjugated anti-rabbit IgG secondary antibody at a 1:2000 dilution in TBST with $0.1 \%$ nonfat dry milk for $1 \mathrm{hr}$ at room temperature. The protein expression signal was detected with Pierce SuperSignal Western Blotting substrate. GAPDH was used as the loading control of sample by reprobing with an anti-GAPDH antibody at a 1:12000 dilution.

\section{Statistical analysis}

Results are expressed as mean \pm standard error of the mean (SEM). For statistical analysis, a Microsoft Excel Data Analysis tool, t-test, was used. The critical value was $95 \%$, and significance was defined as $p<0.05$.

\section{Results}

Growth of mouse pancreatic ductal adenocarcinoma grafts was faster in syngeneic $\mathrm{AT}_{2}-\mathrm{KO}$ mice than in wild type mice

To investigate the influence of the $\mathrm{AT}_{2}$ receptor on tumor growth, we inoculated PAN02 cells into both flanks of syngeneic $\mathrm{AT}_{2}-\mathrm{KO}(\mathrm{n}=6)$ and wild-type $(\mathrm{n}=6) \mathrm{C} 57 \mathrm{BL} / 6$ mice. Our results showed that tumor growth was significantly faster in $\mathrm{AT}_{2}-\mathrm{KO}$ mice than in the control wild type mice (Figure 1). At the time of sacrifice, $\mathrm{AT}_{2}-\mathrm{KO}$ mice had significantly larger tumors than wild type mice (Figure 1), with a mean tumor volume of 642.73 and $263.37 \mathrm{~mm}^{3}$, respectively $(\mathrm{P}<0.05)$. Since real time PCR revealed that primary cultured wild type mouse skin fibroblasts express the $\mathrm{AT}_{2}$ receptor, but PAN02 cells do not (Table 1), these results indicate that the host stromal $\mathrm{AT}_{2}$ receptor is involved in the growth of PAN02 xenografts.

\section{The cell proliferation index was significantly higher in} $\mathrm{AT}_{2}-\mathrm{KO}$ mouse tumors than in wild type mouse tumors

To evaluate cell proliferation in tumors in both types of mice, the cell growth index was analyzed using an antiKi-67 antibody. More Ki-67 positive cells were detected in $\mathrm{AT}_{2}-\mathrm{KO}$ mouse tumor sections than in wild type mouse tumor sections (Figure 2). A detailed examination of the morphology of the Ki-67 positive cells revealed that these cells are tumor cells. In quantitative analysis, the percentage of $\mathrm{Ki}-67$ positive cells is significantly higher in $\mathrm{AT}_{2}-\mathrm{KO}$ mouse tumors than in wild type mouse tumors $(\mathrm{P} \leq 0.001$, Figure $2 \mathrm{C})$. This result indicates that PAN02 tumor growth is faster in $\mathrm{AT}_{2}-\mathrm{KO}$ mice than in wild type mice.

\section{The apoptotic index was lower in $\mathrm{AT}_{2}-\mathrm{KO}$ mouse tumors} than in wild type mouse tumors

The in vivo apoptotic index in tumor tissue from $\mathrm{AT}_{2}-\mathrm{KO}$ and wild type mice was examined by a Terminal Deoxynucleotidyltransferase-Mediated dUTP Nick End Labeling (TUNEL) assay. As shown in Figure 3, although slightly more TUNEL positive cells were detected in tumors from wild type mice than in tumors from $\mathrm{AT}_{2}-\mathrm{KO}$ mice, the difference between the two values was statistically not significant $(P=0.21)$. In addition, apoptotic cells appeared to be a mixture of tumor cells and tumor-infiltrating leukocytes. This result suggests that apoptosis may not be a major contributor to the different tumor growth in the two groups.

\section{Histochemical analysis indicated higher vascular density} in $\mathrm{AT}_{2}-\mathrm{KO}$ mouse tumors than in wild type mouse tumors Overall histochemical analysis of the tumors indicates that they are undifferentiated carcinoma. Occasionally, sarcoma-like morphology was observed in the tumor tissue (Figures $4 \mathrm{~A}$ and $4 \mathrm{~B}$ ). Tumors in both mouse types contain very little stroma. However, vascular endothelial cell staining by anti-von Willebrand factor antibodies revealed that tumors in the $\mathrm{AT}_{2}-\mathrm{KO}$ mice contain significantly more microvasculatures than tumors in wild type mice (Figure 4C and 4D). Average tumor 


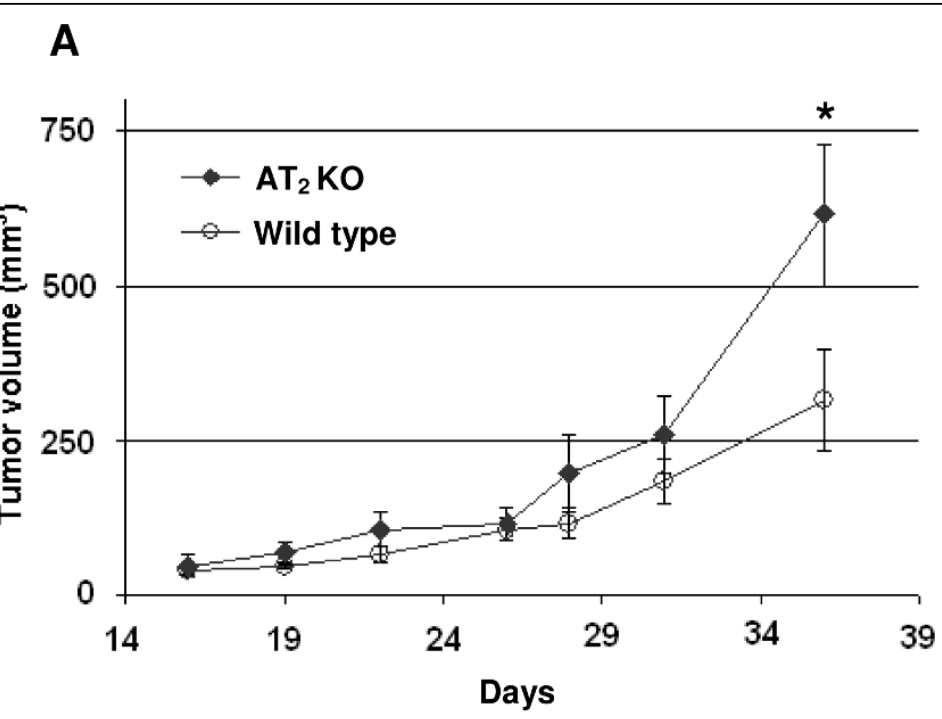

$\mathbf{B}$

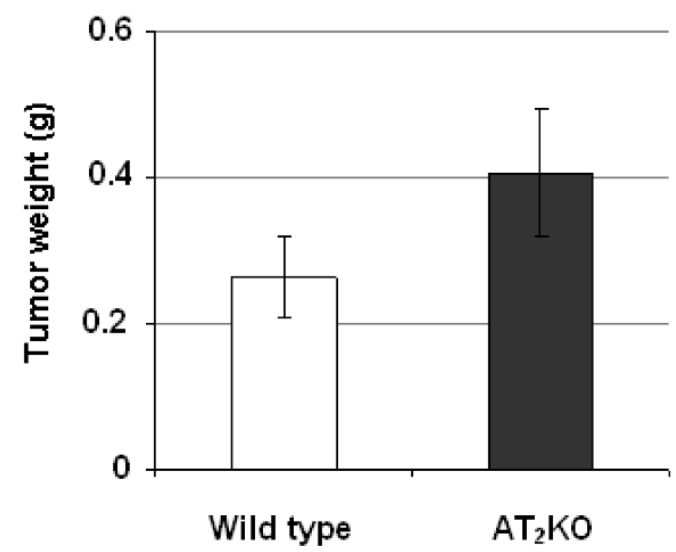

Figure 1 The effect of $\mathrm{AT}_{2}$ receptor deficiency on the growth of murine pancreatic ductal carcinoma (PAN02) xenografts was evaluated in syngeneic mouse model. PANO2 cells $\left(5 \times 10^{6}\right.$ cells suspension in $\left.200 \mu \mathrm{l} P B S\right)$ were inoculated into both flanks in either $\mathrm{AT}_{2}-\mathrm{KO}$ $(n=6)$ or wild type mice $(n=6)$. Tumor volume was calculated after measuring tumor diameter every three to four days using a caliper $(A)$. Tumors were carefully removed at the end of the study and the tumor weight was determined (B). Data are presented as means \pm SEM of twelve tumors from six mice. ${ }^{*} P \leq 0.05$ as compared to the level of wild type mouse group.

vasculature numbers in five randomly chosen fields in wild type and $\mathrm{AT}_{2}-\mathrm{KO}$ mouse tumors was $2.1 \pm 0.5$ and $8.3 \pm 0.1 /$ field, respectively $(\mathrm{p}<0.05)$. Furthermore, immunostaining against VEGF revealed that the cells with morphology similar to fibroblasts in tumor stroma were the primary VEGF positive cells in the tumors. Although VEGF expression in tumor cells was visible, this expression was not as strong as in fibroblastic cells. VEGF positive cells were more abundant in $\mathrm{AT}_{2}-\mathrm{KO}$ mouse tumors than in wild type mouse tumors (4.2 vs. 7.8/field, respectively, $\mathrm{P}=0.15$ ), although the difference between two groups was not statistically significant due to large variation. These results suggest that faster tumor growth in $\mathrm{AT}_{2}-\mathrm{KO}$ mice may be associated with development of tumor microvasculature. Results further
Table 1 Expression of both angiotensin II $A T_{1}$ and $A T_{2}$ receptors was detected in wild-type mouse skin fibroblasts (MSF) but not in PAN02 cells

\begin{tabular}{|c|c|c|c|c|c|c|}
\hline \multirow{2}{*}{$\begin{array}{l}\text { Genes } \\
\text { Serum }\end{array}$} & \multicolumn{2}{|c|}{$\mathrm{AT}_{1}$} & \multicolumn{2}{|c|}{$\mathrm{AT}_{2}$} & \multicolumn{2}{|c|}{$18 \mathrm{~S}$} \\
\hline & + & - & + & - & + & - \\
\hline MSF & 22.8 & 23.5 & 28.1 & 20.6 & 11.9 & 12.8 \\
\hline PAN02 & 29.6 & 29.7 & 29.4 & 29.7 & 10.0 & 11.3 \\
\hline $\mathrm{H}_{2} \mathrm{O}$ & \multicolumn{2}{|c|}{30.6} & \multicolumn{2}{|c|}{30.0} & \multicolumn{2}{|c|}{29.8} \\
\hline
\end{tabular}

Ang II receptor expression in wild-type MSF and PAN02 cells was determined by real-time PCR and expressed as threshold cycle $(\mathrm{Ct})$ value. The $18 \mathrm{~S}$ ribosomal RNA was used as an internal standard. The $\mathrm{Ct}$ value indicates the fractional cycle number at which the amount of amplified target reaches a fixed threshold. Cells were cultured in either serum-containing or serum-free medium for two days, total RNA was extracted, and the receptor expression was determined. The values represent the average of triplicate determinations. Serum-free culture is known to increase $\mathrm{AT}_{2}$ expression in cultured cells [34]. 

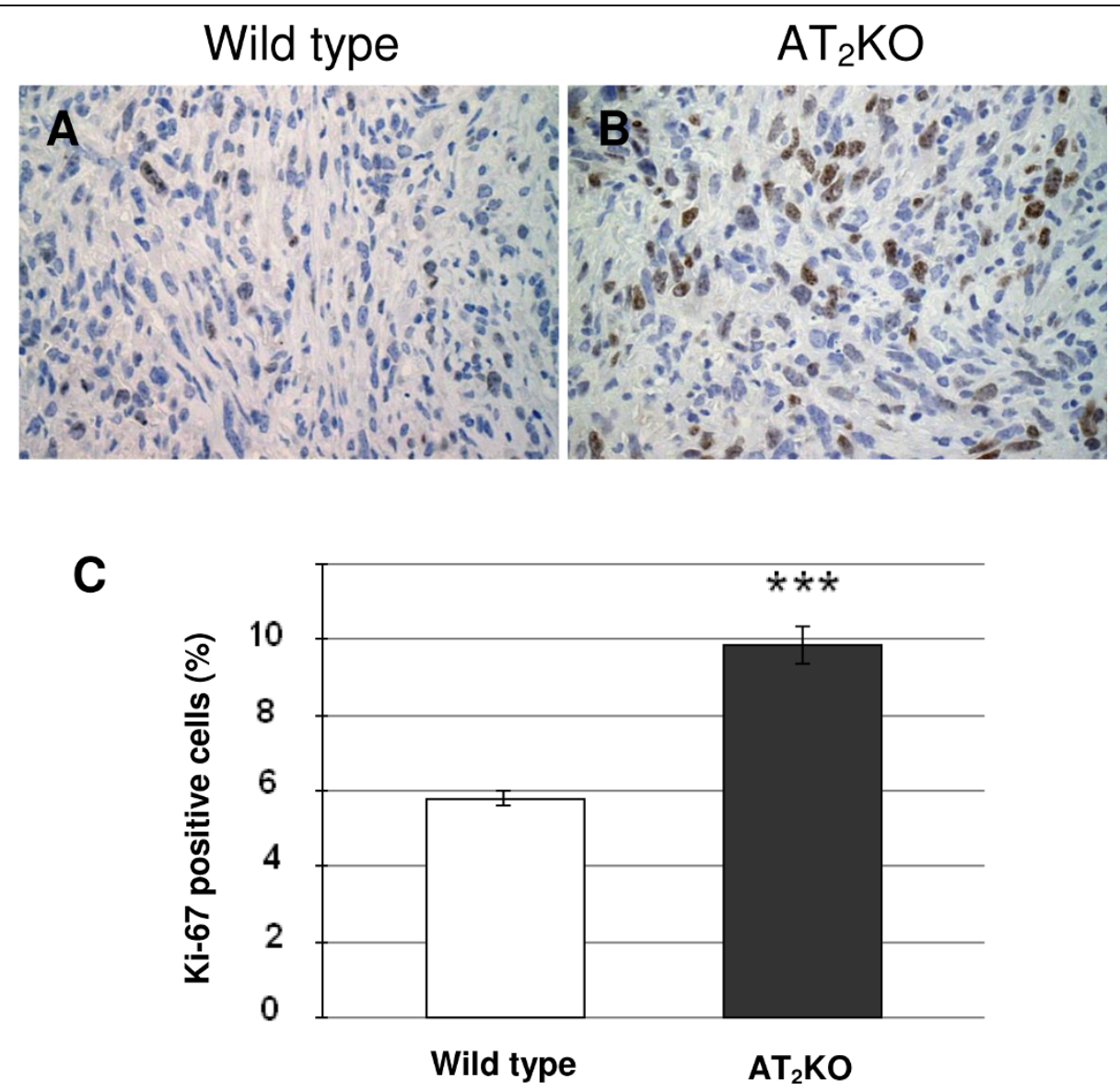

Figure 2 Cell proliferation in tumor tissues was analyzed by counting anti-Ki-67 antibody positive cells in wild type (A) and in $\mathrm{AT}_{2}-\mathrm{KO}$ mice (B). Quantitative analysis of cell proliferation (C) was carried out by counting anti-Ki-67 antibody positive and negative cells in five random view fields; mean \% positive cells was calculated from this raw data for graphical presentation. Data are presented as percentages \pm SEM of Ki67 positive cells/field. Original magnification of each panel is $400 \times{ }^{*} P \leq 0.001$ as compared to the level of wild type mouse group.

suggest that the tumor stromal fibroblasts may play an important role in tumor growth.

\section{Angiotensin II stimulated growth of PAN02 cells co-} cultured with fibroblasts, and this stimulation was further increased by an $\mathrm{AT}_{2}$ receptor specific antagonist

To evaluate the effects of Ang II and the $\mathrm{AT}_{2}$ receptor signaling on the growth of PAN02 cells in vitro, the effect of a low concentration of Ang II (10 nM) was examined on the growth of PAN02 cells co-cultured with MSFs prepared from either wild type or $\mathrm{AT}_{2}-\mathrm{KO}$ mice or with $\mathrm{AT}_{2}$ receptor over-expressing MSFs prepared from either wild type or $\mathrm{AT}_{2}-\mathrm{KO}$ mice. Since $\mathrm{AT}_{2}$ receptor expression is known to be attenuated in culture [34], $\mathrm{AT}_{2}$ receptor expression should be assured by the receptor over-expression. As shown in Figure 5, growth of PAN02 was significantly attenuated when the $\mathrm{AT}_{2}$ receptor was over-expressed in co-cultured MSFs. Ang II only slightly increased the growth of PAN02 cells regardless of cell sources (wild type or $\mathrm{AT}_{2}-\mathrm{KO}$ mice) or AT2 expression in MSFs. However, Ang II significantly increased cell growth of PAN02 co-cultured with $\mathrm{AT}_{2}$-over-expressing MSFs when cells were treated with the $\mathrm{AT}_{2}$ receptor-specific antagonist PD123319 (10 $\left.\mu \mathrm{M}\right)$. This $\mathrm{AT}_{2}$ receptor blockade effect was not observed when control Lac Z transfected MSFs were used in this experiment (data not shown). Ang II or PD123319 treatment did not show any significant effect on the growth of MSFs derived from either wild type or $\mathrm{AT}_{2}-\mathrm{KO}$ mice (data not shown). These results indicate that $\mathrm{AT}_{2}$ expression in co-cultured MSFs plays a negative role in cell proliferation of PAN02 cells and this effect can be reversed by the $\mathrm{AT}_{2}$ receptor blockade.

\section{Angiotensin II attenuated VEGF production in fibroblasts,} and this attenuation was blocked by an $\mathrm{AT}_{2}$ receptor specific antagonist

To evaluate a potential mechanism by which stromal cells regulate PAN02 tumor growth, the effect of a low concentration of Ang II (10 nM) on VEGF production 


\section{Wild type}
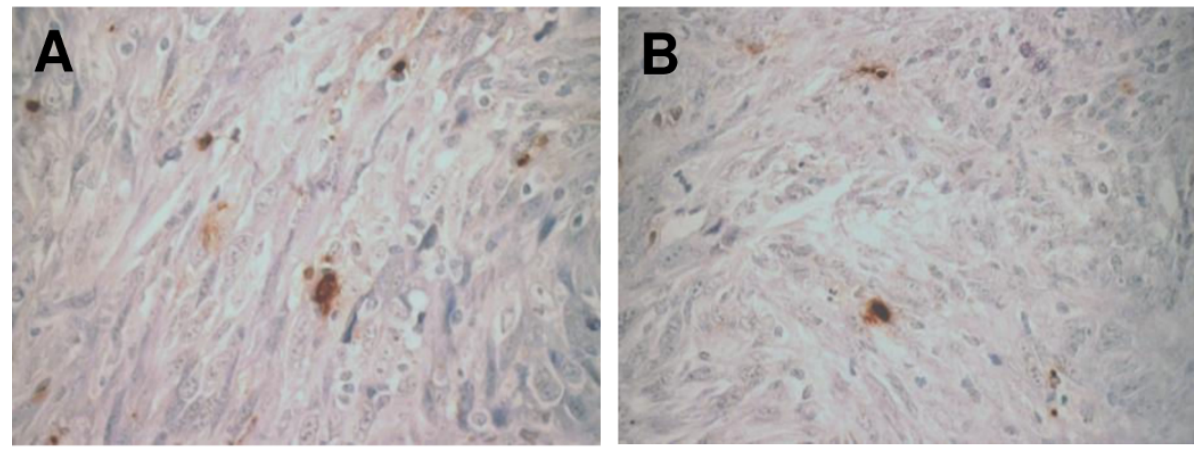

C

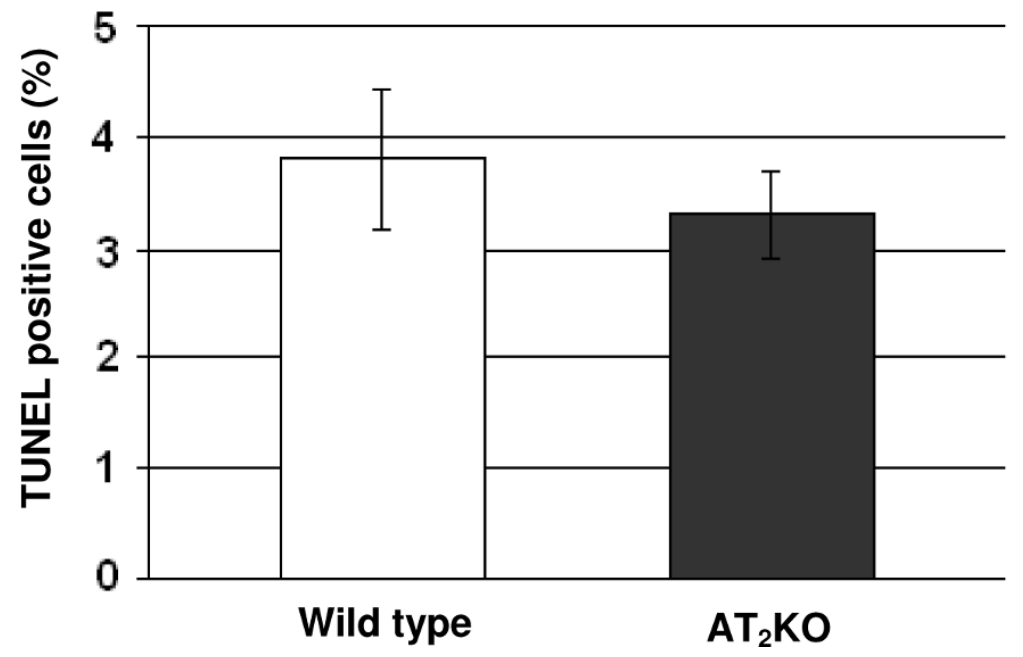

Figure 3 Apoptosis in tumor tissues was analyzed by visualizing TUNEL positive cells in wild type (A) and $\mathrm{AT}_{2}-\mathrm{KO}(\mathrm{B})$ mouse tumors. Quantitative analysis of apoptosis (C) was carried out by counting TUNEL positive and negative cells in five random view fields; mean \% positive cells was calculated from this raw data for graphical presentation. Data are presented as percentages \pm SEM of TUNEL positive cells/field. The original magnification of each panel is $400 \times$.

in wild type MSFs was examined. As shown in Figure 6, Ang II attenuated VEGF protein expression in MSFs, and this attenuation was completely blocked when cells were pre-treated with the $\mathrm{AT}_{2}$ receptor-specific antagonist PD123319 $(10 \mu \mathrm{M})$. PD123319 treatment alone slightly increased VEGF expression in MSFs (Figure 6). These results suggest that $\mathrm{AT}_{2}$-mediated Ang II signaling plays a negative role in VEGF expression in MSFs. This may imply that Ang II-dependent regulation of VEGF production in stromal cells may play an important role in PAN02 tumor growth.

\section{Discussion}

Increasing evidence suggests that Ang II signaling plays an important role in carcinogenesis [15,19,22,35-37]. While $\mathrm{AT}_{1}$ receptor over-expression has been implicated in many types of cancers including pancreatic cáncer $[11,12,38,39]$, the specific role of the $\mathrm{AT}_{2}$ receptor in carcinogenesis has not been rigorously elucidated. We have previously demonstrated the prooncogenic role of the $\mathrm{AT}_{2}$ receptor in carcinogeninduced colon and lung tumorigenesis in the mouse. In these models, the $\mathrm{AT}_{2}$ receptor appears to enhance carcinogen metabolism and increase tumorigenesis. However, the effect of $\mathrm{AT}_{2}$ receptor-mediated signaling on tumor growth is unknown. Since Ang II has been shown to stimulate tumor growth through the $\mathrm{AT}_{1}$ receptor $[35,39,40]$, and since the $\mathrm{AT}_{2}$ receptor antagonizes the $\mathrm{AT}_{1}$ receptor [41,42], it is relevant to study the role of the $\mathrm{AT}_{2}$ receptor in tumor growth. Therefore, in this study we sought to evaluate the role of $\mathrm{AT}_{2}$ receptor expression in stroma in the growth of pancreatic ductal adenocarcinoma, the most common form of pancreatic cancer. 


\section{Wild type}
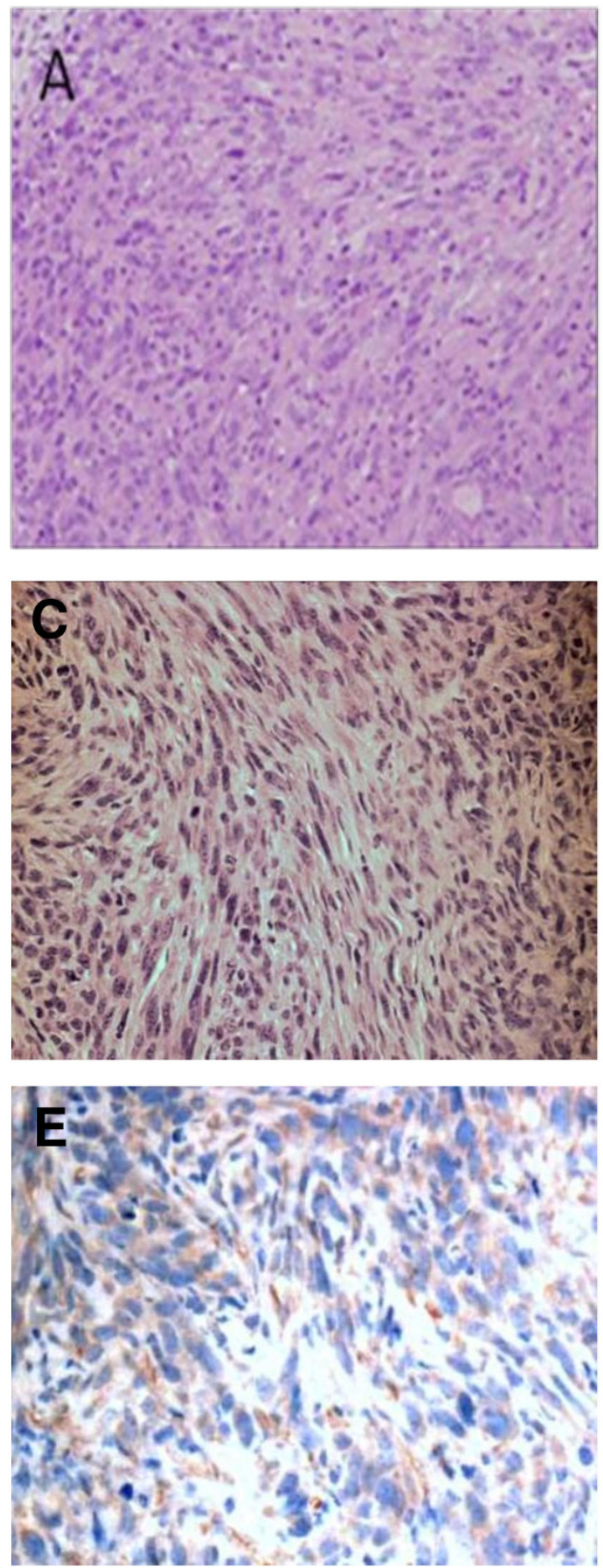

$\mathrm{AT}_{2} \mathrm{KO}$
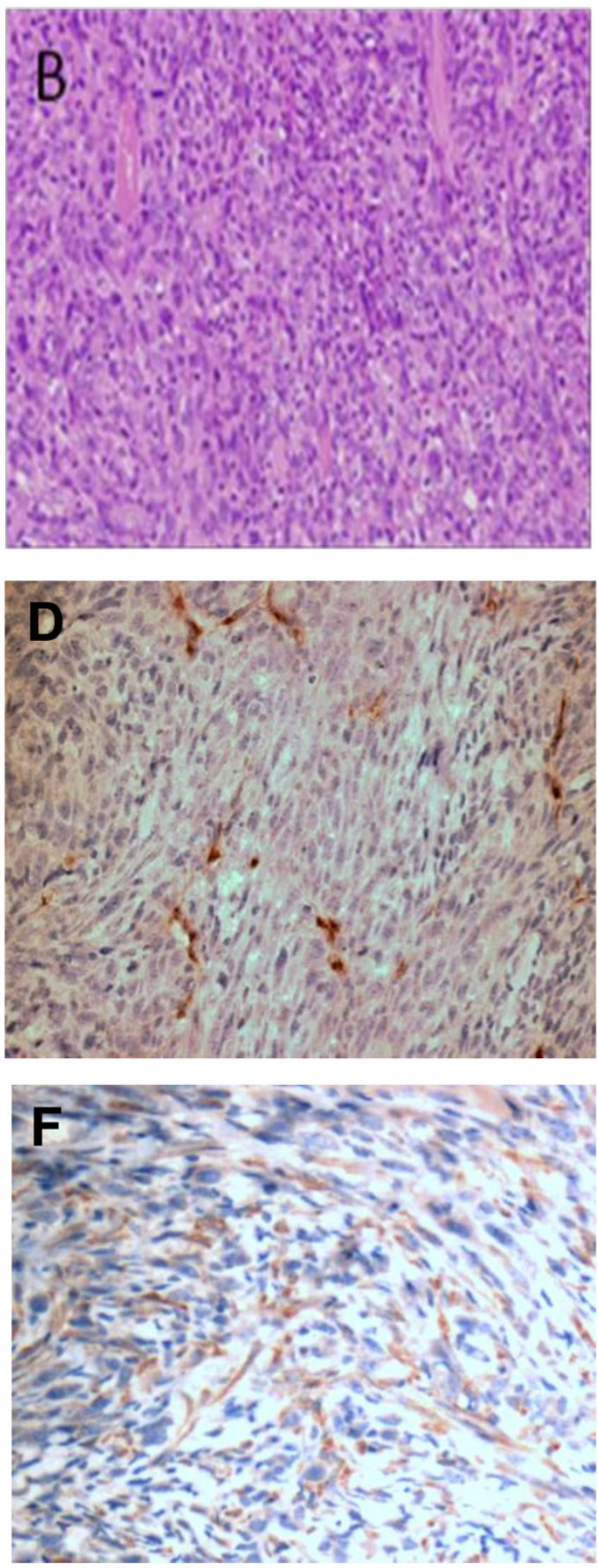

Figure 4 Tumor morphology in wild type (A) and $\mathrm{AT}_{2}-\mathrm{KO}$ mice (B) was studied after hematoxylin and eosin staining. Tumor vessel density in wild-type $(C)$ and $\mathrm{AT}_{2}-\mathrm{KO}$ mouse tumors $(\mathrm{D})$ was studied after endothelial cell staining using vascular endothelial cell-specific anti-von Willebrand factor antibodies. Average tumor vasculature numbers in AT2-KO mouse tumors ( $8.3 \pm 0.1 /$ field) were significantly higher than in wild type tumors (2.1 $\pm 0.5 /$ field, $p<0.05)$. VEGF expression in wild-type $(E)$ and $A T_{2}-K O$ mouse tumors $(F)$ was also studied after VEGF

immunostaining using anti-VEGF antibodies. The original magnification of panels $A$ and $B$ is $200 \times$ and panels $C, D, E$, and $F$ is $400 \times$. 


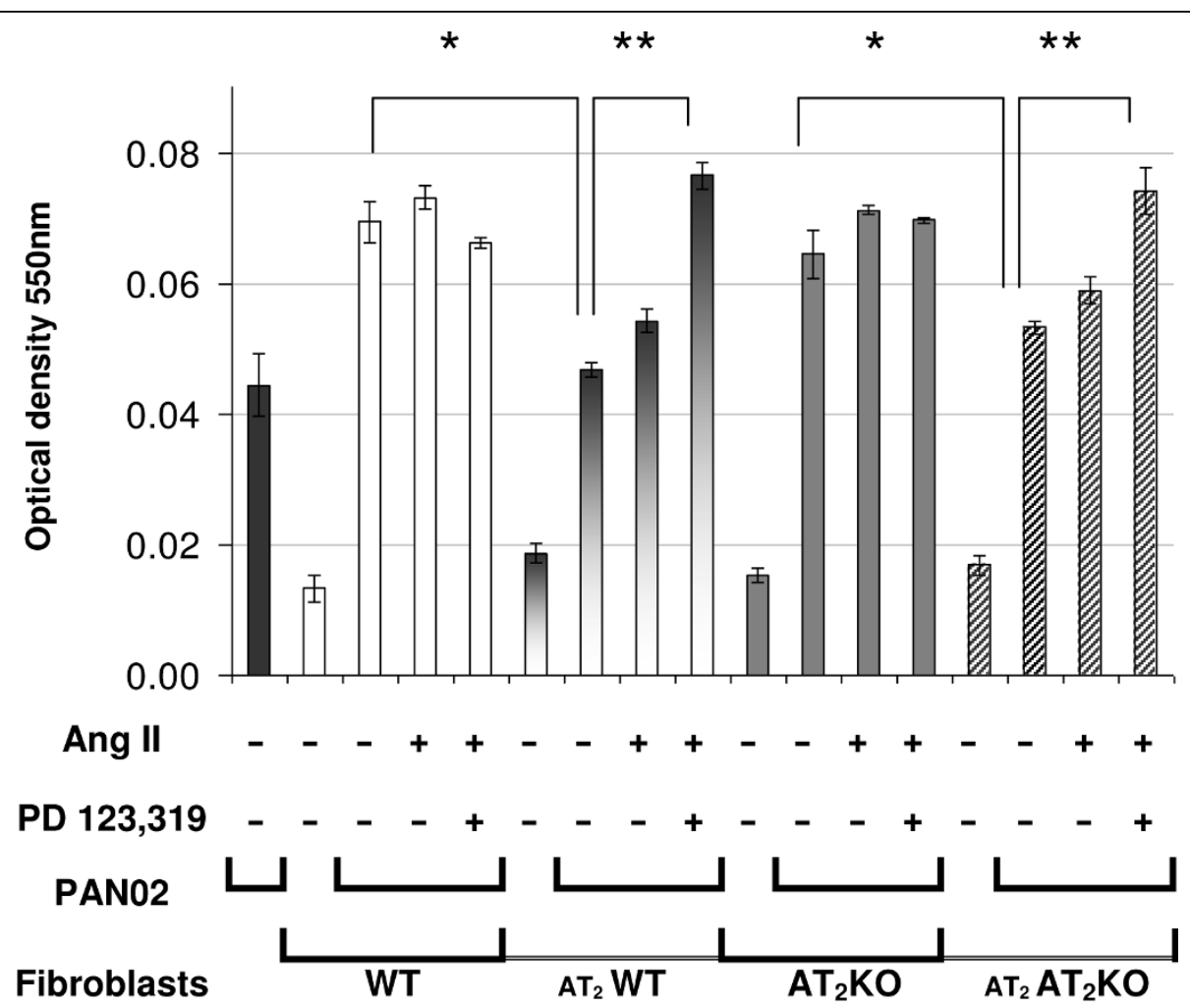

Figure 5 The effect of Ang II and an $\mathrm{AT}_{2}$ receptor antagonist on cell proliferation, as determined by MTT assay, of PAN02 cells (black solid bars) co-cultured with MSFs prepared from either wild type (WT) mice (untransfected WT fibroblasts, WT, open bars; and AT 2 over-expressing WT fibroblasts, $\mathrm{AT}_{2} \mathrm{WT}$, half-shaded bars) or $\mathrm{AT}_{2}-\mathrm{KO}$ mice (untransfected $\mathrm{AT}_{2}-\mathrm{KO}$ fibroblasts, $\mathrm{AT}_{2} \mathrm{KO}$, dark grey bars; and $A T_{2}$ over-expressing $A T_{2}-K O$ fibroblasts ${ }_{A T 2} A T_{2} K O$, hashed bars). Untransfected or $A T_{2}$ transfected primary cultured mouse skin fibroblasts were cultured one day prior to the initiation of PAN02 co-culture. The ratio of fibroblasts to PAN02 cells was 1:4. The cells were treated with Ang II (10 nM) in the presence or absence of the AT ${ }_{2}$-specific antagonist PD123,319 $(10 \mu \mathrm{M})$ as indicated in the figure. Cell proliferation was determined $72 \mathrm{~h}$ after Ang II treatment by MTT assay as described in the Methods. The average (means \pm SEM) of three separate experiments is displayed in the histogram. Cell proliferation of PAN02 co-cultured with $\mathrm{AT}_{2}$ over-expressing fibroblasts was significantly lower than that with untransfected fibroblasts regardless of the cell source $\left.{ }^{*}, \mathrm{P} \leq 0.05\right)$, whereas PAN02 proliferation was significantly increased when cells were treated with the $\mathrm{AT}_{2}$ antagonist PD123,319 (** $\mathrm{P} \leq 0.01$ ).

In the first study, we have examined the growth of PAN02 adenocarcinoma cells in $\mathrm{AT}_{2}-\mathrm{KO}$ and wild type mice and found that the growth of PAN02 xenografts is significantly faster in $\mathrm{AT}_{2}-\mathrm{KO}$ mice than in wild type mice (Figure 1). The degree of cell proliferation and the index of apoptosis were measured by anti-Ki-67 staining and TUNEL assay, respectively. It was found that anti-Ki-67 positive staining was significantly higher in $\mathrm{AT}_{2}-\mathrm{KO}$ mouse tumors than in wild type mouse tumors (Figure 2). It was also observed that the index of apoptosis is slightly higher in the wild type mouse tumors than in $\mathrm{AT}_{2}-\mathrm{KO}$ mouse tumors, although there was no statistical difference between the two groups (Figure 3). In addition, tumor vessel density was significantly higher in $\mathrm{AT}_{2}-\mathrm{KO}$ mice than in wild type mice (Figure 4). At a glance, the in vivo results show that growth of PAN02 cells was significantly faster in the $\mathrm{AT}_{2}-\mathrm{KO}$ environment than in the wild type environment, most likely due to a high degree of cell proliferation. Higher tumor vessel density may also be associated with faster tumor growth in the $\mathrm{AT}_{2}-\mathrm{KO}$ mice.

Following the in vivo mouse study, in vitro studies were carried out to determine the mechanism by which $\mathrm{AT}_{2}$ receptor expression in stromal cells modifies the growth of pancreatic carcinoma cells. In the first in vitro experiment, the effect of $\mathrm{AT}_{2}$ receptor over-expression in either wild type or $\mathrm{AT}_{2}$-KO MSFs was evaluated in co-culture with PAN02 cells. Results clearly indicate that $\mathrm{AT}_{2}$ receptor over-expression significantly attenuates growth of co-cultured PAN02 cells. However, this attenuation was completely abolished by the addition of a low concentration of Ang II in the presence of the $\mathrm{AT}_{2}$ receptor-specific blocker PD123319 (Figure 5). Since the contribution of MSFs to cell proliferation is approximately one third of the total cell proliferation (MSF + PAN02), since MSF cell proliferation was not influenced by the status of $\mathrm{AT}_{2}$ receptor expression (Figure 5) nor by the presence of Ang II or the $\mathrm{AT}_{2}$ 

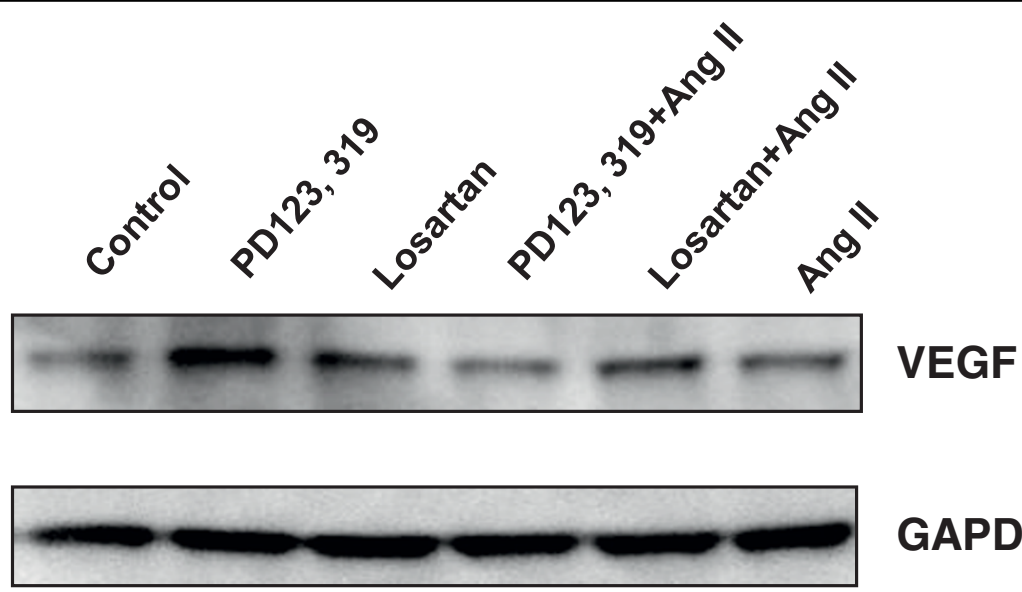

\section{GAPDH}

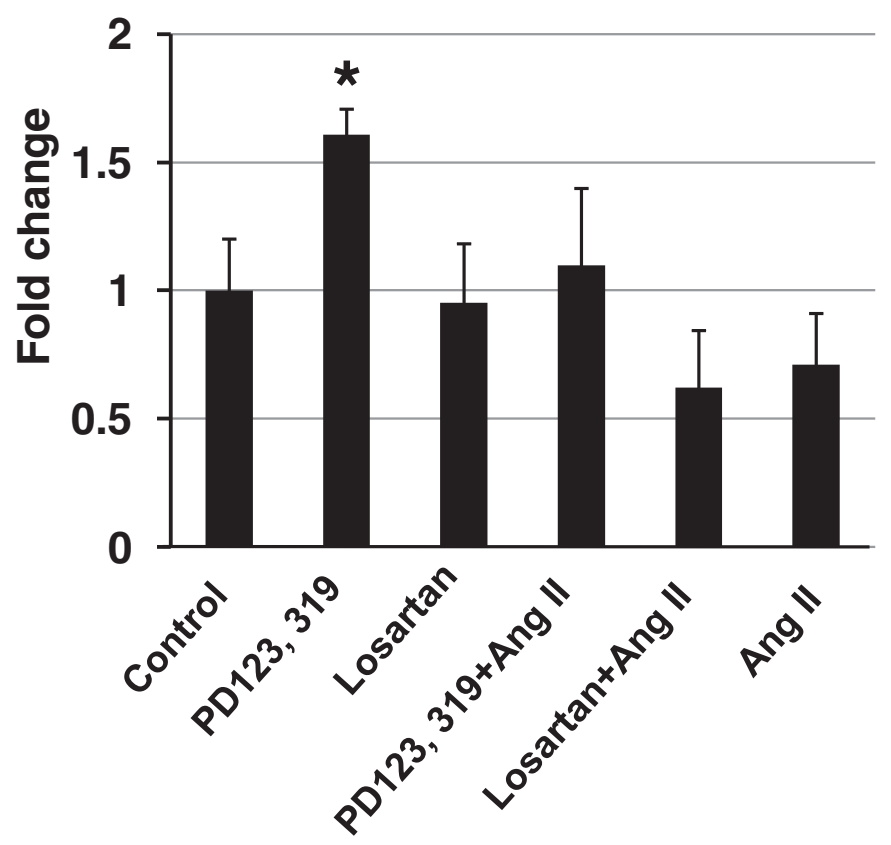

Figure 6 The effect of Ang II and an $\mathrm{AT}_{2}$ receptor antagonist on VEGF protein expression in mouse fibroblasts was determined by Western blot analysis. Primary cultured mouse skin fibroblasts were treated with Ang $\|(10 \mathrm{nM})$ in the presence or absence of the $A T_{1}$ - and $\mathrm{AT}_{2}$-specific antagonists Losartan $(1 \mu \mathrm{M})$ and PD123,319 $(10 \mu \mathrm{M})$, respectively, as indicated in the figure. VEGF protein was determined $48 \mathrm{~h}$ after Ang II treatment by Western blot analysis as described in the Methods. The average (means \pm SEM) of two separate experiments is displayed in the histogram. Ang II attenuated VEGF expression $(P=0.1$ ), but this attenuation was completely blocked by the AT 2 antagonist PD123,319. However, PD123,319 treatment significantly increased VEGF production as compared to untreated control $(*, P \leq 0.05)$.

antagonist (data not shown), and since PAN02 cells do not express Ang II receptors, the growth of PAN02 cells appears to be indirectly regulated by the MSFs. This experiment nicely recapitulates results obtained from the mouse study (Figure 1). Furthermore, VEGF expression in MSFs was shown to be suppressed by Ang II$\mathrm{AT}_{2}$ receptor signaling (Figure 6), implying that $\mathrm{AT}_{2}$ receptor expression-dependent growth attenuation may be mediated by the attenuation of VEGF production in stromal fibroblasts. In support of this, the VEGF positive cell numbers were higher in $\mathrm{AT}_{2}-\mathrm{KO}$ mouse tumors than in the wild type mouse tumors (Figure 4). Taken together, these results strongly suggest that $\mathrm{AT}_{2}$ receptor signaling in stromal cells plays an important role in inhibition of tumor growth. As this research shows, tumor growth regulation is indirectly controlled through stromal cells. The significance of tumor stromal cells in tumor growth is widely accepted [43] and further emphasized by another recent report [44]. The mechanism by which tumor stromal fibroblasts regulate tumor 
growth has not been rigorously studied. However, Sugimoto et al. suggest that hepatocyte growth factor produced in fibroblasts controls tumor growth[45]. Since Ang II is known to be produced in fibroblasts and acts as a local cell growth regulator $[10,15]$, it is reasonable to speculate that Ang II also plays a role as a local mediator for tumor growth. In support of this speculation, Fujimoto et al. [39] have reported $\mathrm{AT}_{1}$ receptor overexpression in human pancreatic cancer tissues and $\mathrm{AT}_{1}$ receptor-mediated growth regulation in pancreatic cancer cells. Furthermore, Anandanadesan has also reported that Ang II stimulates VEGF expression in a panel of human pancreatic cancer cell lines [38]. The present study also indicates that tumor stromal fibroblasts appear to be a rich source of VEGF (Figure 4).

It is well known that the Ang II receptor has two major isoforms, and their signaling is associated with cell proliferation and apoptosis [20]. The major isoform, the $\mathrm{AT}_{1}$ receptor, is expressed in a wide variety of tissues, and its signaling functions in a variety of pathophysiological reactions, including constriction of blood vessels, induction of cell proliferation and expression of proto-oncogenes such as c-fos, c-myc and c-jun [46]. The second major isoform, the $\mathrm{AT}_{2}$ receptor, is abundantly expressed in fetal tissues, but its expression declines rapidly after birth [14]. Multiple studies have shown that $\mathrm{AT}_{2}$ receptor signaling counteracts the biological effects mediated by AT1 receptor signaling, including inhibition of cell proliferation $[41,42,47]$. Therefore, the delicate balance between the activities of these two receptors plays an important role in the pathophysiology of various diseases[20]. Accordingly, $\mathrm{AT}_{2}$ receptor-deficiency-induced tumor growth stimulation may be mediated at least in part through Ang II$\mathrm{AT}_{1}$ receptor signaling in either stromal cells or cancer cells. Indeed, it has been well documented that Ang II, besides its conventional physiological actions, displays characteristics of a growth factor [48]. The $\mathrm{AT}_{2}$ receptor signaling-dependent cell growth attenuation reported here is in good agreement with earlier studies $[41,49]$. In these studies, growth of vascular endothelial cells and smooth muscle cells were shown to be attenuated by $\mathrm{AT}_{2}$ receptor-mediated Ang II signaling. Although these studies did not clarify the potential second messenger that controls cell growth, the present study suggests that AT2 receptor-mediated attenuation of VEGF production is a potential mechanism for $\mathrm{AT}_{2}$ receptor expression-dependent growth attenuation of pancreatic carcinoma.

Based on observations by other researchers $[20,21,48,50,51]$ and findings in the present study, it is clear that the $\mathrm{AT}_{2}$ receptor plays an important role in tumor growth in rodents. To the best of our knowledge, this is the first report to describe the involvement of
$\mathrm{AT}_{2}$ receptor mediated signaling in controlling the growth of pancreatic adenocarcinoma at least in part by attenuating stromal fibroblast-dependent VEGF production. However, whether $\mathrm{AT}_{2}$ receptor expression indeed plays an important role in human pancreatic cancer growth must be clarified by human clinical studies.

\section{Conclusion}

The present study clearly indicates that the Ang II-AT receptor signaling plays an important role in the growth regulation of pancreatic adenocarcinoma. Thus, it is suggested that the $\mathrm{AT}_{2}$ receptor could be an important target for cancer therapy/chemoprevention.

\section{Abbreviations}

ABC: avidin-biotin peroxidase complex; Ang II: angiotensin II; $\mathrm{TT}_{2}$ : angiotensin II (Ang II) type 2 receptor; $A T_{2}-K O$ : $A T_{2}$ receptor-deficient; VEGF: vascular endothelial growth factor; EGF: epidermal growth factor; FBS: fetal bovine serum; MAPK: mitogen-activated protein kinase; MEK: MAPK kinase 1; MSFs: mouse skin fibroblasts; MTT: Methylthiazol Tetrazolium; PAN02: pancreatic carcinoma; PDAC: pancreatic ductal adenocarcinoma; TUNEL: terminal Deoxynucleotidyltransferase-Mediated dUTP Nick End Labeling; vWF: von Willebrand factor.

\section{Acknowledgements}

This work was supported in part by the Kansas State University (KSU) Terry C. Johnson Center for Basic Cancer Research, KSU College of Veterinary Medicine Dean's fund, KSU Targeted Excellence Research grant, Kansas State Legislative Appropriation and NIH grants 1R21CA135599, P20 RR017686 and 5P20RR015563.

\section{Author details}

${ }^{1}$ Department of Anatomy \& Physiology, Kansas State University, College of Veterinary Medicine, Manhattan, KS 66506, USA. ²Department of Pathology, Tokai University School of Medicine, Isehara, Kanagawa 259-1193, Japan.

\section{Authors' contributions}

$C D, N E$ and AK equally contributed to this study. CD, NE, AK, NO, DU, RA, LP $\mathrm{YI}$ and MT were responsible for the study design, experimental work, data evaluation and analysis, and drafting the manuscript. DKM, DT, and ST were consulted extensively in the experimental design and interpretation of results, as well as in the preparation of the manuscript. MT was the research supervisor and participated in the study design, assessment of the results, and drafting the manuscript. All authors read and approved the manuscript.

\section{Competing interests}

The authors declare that they have no competing interests.

\section{Received: 8 May 2009}

Accepted: 24 February 2010 Published: 24 February 2010

\section{References}

1. Warshaw AL, Fernandez-del Castillo C: Pancreatic carcinoma. N Engl J Med 1992, 326(7):455-465

2. Hezel AF, Kimmelman AC, Stanger BZ, Bardeesy N, Depinho RA: Genetics and biology of pancreatic ductal adenocarcinoma. Genes Dev 2006, 20(10):1218-1249.

3. Jemal A, Siegel R, Ward E, Hao Y, Xu J, Thun MJ: Cancer Statistics, 2009. CA Cancer J Clin 2009, 59(4):225-49.

4. Keleg S, Buchler P, Ludwig R, Buchler MW, Friess $H$ : Invasion and metastasis in pancreatic cancer. Mol Cancer 2003, 2:14.

5. McKenna S, Eatock M: The medical management of pancreatic cancer: a review. Oncologist 2003, 8(2):149-160.

6. Kleeff J, Reiser C, Hinz U, Bachmann J, Debus J, Jaeger D, Friess H, Buchler MW: Surgery for recurrent pancreatic ductal adenocarcinoma. Ann Surg 2007, 245(4):566-572. 
7. Stoll $M$, Unger T: Angiotensin and its AT2 receptor: new insights into an old system. Regul Pept 2001, 99(2-3):175-182.

8. Thomas WGMF: Molecules in Focus Angiotensin receptors: form and distribution. IJBCB 2003, 35:774-779

9. Timmermans PB, Wong PC, Chiu AT, Herblin WF, Benfield P, Carini DJ, Lee RJ, Wexler RR, Saye JA, Smith RD: Angiotensin II receptors and angiotensin II receptor antagonists. Pharmacol Rev 1993, 45(2):205-251.

10. Berry C, Touyz R, Dominiczak AF, Webb RC, Johns DG: Angiotensin receptors: signaling, vascular pathophysiology, and interactions with ceramide. Am J Physiol Heart Circ Physiol 2001, 281(6):H2337-2365.

11. Fyhrquist F, Saijonmaa O: Renin-angiotensin system revisited. J Intern Med 2008, 264(3):224-236

12. Hunyady L, Catt KJ: Pleiotropic AT1 receptor signaling pathways mediating physiological and pathogenic actions of angiotensin II. Mol Endocrinol 2006, 20(5):953-970.

13. Grady EF, Sechi LA, Griffin CA, Schambelan M, Kalinyak JE: Expression of AT2 receptors in the developing rat fetus. J Clin Invest 1991, 88(3):921-933.

14. Prowse KR, Greider CW: Developmental and tissue-specific regulation of mouse telomerase and telomere length. Proc Natl Acad Sci USA 1995, 92(11):4818-4822.

15. Kanehira T, Tani T, Takagi T, Nakano Y, Howard EF, Tamura M: Angiotensin II type 2 receptor gene deficiency attenuates susceptibility to tobaccospecific nitrosamine-induced lung tumorigenesis: involvement of transforming growth factor-beta-dependent cell growth attenuation. Cancer Res 2005, 65(17):7660-7665.

16. Puolakkainen PA, Brekken RA, Muneer S, Sage EH: Enhanced growth of pancreatic tumors in SPARC-null mice is associated with decreased deposition of extracellular matrix and reduced tumor cell apoptosis. Molecular Cancer Research 2004, 2(4):215-224.

17. Teicher BA: Tumor Models in Cancer Research. Human Press, NJ 2002.

18. Mazzolini G, Narvaiza I, Martinez-Cruz LA, Arina A, Barajas M, Galofré JC, Qian C, Mato JM, Prieto J, Melero I: Pancreatic cancer escape variants that evade immunogene therapy through loss of sensitivity to IFNgammainduced apoptosis. Gene Therapy 2003, 10(13):1067-1078.

19. Fujita M, Hayashi I, Yamashina S, Fukamizu A, Itoman M, Majima M: Angiotensin type 1a receptor signaling-dependent induction of vascular endothelial growth factor in stroma is relevant to tumor-associated angiogenesis and tumor growth. Carcinogenesis 2005, 26(2):271-279.

20. Cao Z, Kelly DJ, Cox A, Casley D, Forbes JM, Martinello P, Dean R, Gilbert RE, Cooper ME: Angiotensin type 2 receptor is expressed in the adult rat kidney and promotes cellular proliferation and apoptosis. Kidney Int 2000, 58:2437-2451

21. Antus B, Mucsi I, Rosivall L: Apoptosis induction and inhibition of cellular proliferation by angiotensin II: possible implication and perspectives. Acta Physiol Hung 2000, 87(1):5-24.

22. Takagi T, Nakano $Y$, Takekoshi S, Inagami T, Tamura M: Hemizygous mice for the angiotensin II type 2 receptor gene have attenuated susceptibility to azoxymethane-induced colon tumorigenesis. Carcinogenesis 2002, 23(7):1235-1241.

23. Steckelings UM, Henz BM, Wiehstutz S, Unger T, Artuc M: Differential expression of angiotensin receptors in human cutaneous wound healing. $\mathrm{Br} J$ Dermatol 2005, 153(5):887-893.

24. Utsunomiya H, Nakamura M, Kakudo K, Inagami T, Tamura M: Angiotensin II AT2 receptor localization in cardiovascular tissues by its antibody developed in AT2 gene-deleted mice. Regul Pept 2005, 126(3):155-161.

25. Ulmasov $B, X u Z$, Tetri LH, Inagami T, Neuschwander-Tetri BA: Protective role of angiotensin II type 2 receptor signaling in a mouse model of pancreatic fibrosis. Am J Physiol Gastrointest Liver Physiol 2009, 296(2): G284-294.

26. Reddy MK, Baskaran K, Molteni A: Inhibitors of angiotensin-converting enzyme modulate mitosis and gene expression in pancreatic cancer cells. Proc Soc Exp Biol Med 1995, 210(3):221-226.

27. Volpert OV, Ward WF, Lingen MW, Chesler L, Solt DB, Johnson MD, Molteni A, Polverini PJ, Bouck NP: Captopril inhibits angiogenesis and slows the growth of experimental tumors in rats. J Clin Invest 1996, 98(3):671-679.

28. Hii SI, Nicol DL, Gotley DC, Thompson LC, Green MK, Jonsson JR: Captopril inhibits tumour growth in a xenograft model of human renal cell carcinoma. Br J Cancer 1998, 77(6):880-883.
29. Prontera C, Mariani B, Rossi C, Poggi A, Rotilio D: Inhibition of gelatinase A (MMP-2) by batimastat and captopril reduces tumor growth and lung metastases in mice bearing Lewis lung carcinoma. Int I Cancer 1999, 81(5):761-766.

30. Yoshiji H, Kuriyama S, Kawata M, Yoshii J, Ikenaka Y, Noguchi R, Nakatani T, Tsujinoue H, Fukui $H$ : The angiotensin-I-converting enzyme inhibitor perindopril suppresses tumor growth and angiogenesis: possible role of the vascular endothelial growth factor. Clin Cancer Res 2001, 7(4):1073-1078.

31. Lever AF, Hole DJ, Gillis CR, McCallum IR, McInnes GT, Mackinnon PL, Meredith PA, Murray LS, Reid JL, Robertson JW: Do inhibitors of angiotensin-l-converting enzyme protect against risk of cancer?. Lancet 1998, 352(9123):179-184.

32. Kambayashi Y, Bardhan S, Takahashi K, Tsuzuki S, Inui H, Hamakubo T, Inagami T: Molecular cloning of a novel angiotensin II receptor isoform involved in phosphotyrosine phosphatase inhibition. J Biol Chem 1993, 268(33):24543-24546.

33. Ayuzawa A, Doi C, Rachakatla RS, Pyle MM, Maurya DK, Troyer D, Tamura M: Naïve human umbilical cord matrix derived stem cells significantly attenuate growth of human breast cancer cells in vitro and in vivo. Cancer letters 2009, 280(1):31-37.

34. Ichiki T, Kambayashi $Y$, Inagami T: Differential inducibility of angiotensin II AT2 receptor between SHR and WKY vascular smooth muscle cells. Kidney Int Suppl 1996, 55:S14-17.

35. Egami K, Murohara T, Shimada T, Sasaki K, Shintani S, Sugaya T, Ishii M, Akagi T, Ikeda H, Matsuishi T, et al: Role of host angiotensin II type 1 receptor in tumor angiogenesis and growth. J Clin Invest 2003, 112(1):67-75.

36. Suganuma T, Ino K, Shibata K, Kajiyama H, Nagasaka T, Mizutani S, Kikkawa F: Functional expression of the angiotensin II type 1 receptor in human ovarian carcinoma cells and its blockade therapy resulting in suppression of tumor invasion, angiogenesis, and peritoneal dissemination. Clin Cancer Res 2005, 11(7):2686-2694.

37. Ino K, Shibata K, Kajiyama H, Yamamoto E, Nagasaka T, Nawa A, Nomura S, Kikkawa F: Angiotensin II type 1 receptor expression in ovarian cancer and its correlation with tumour angiogenesis and patient survival. $\mathrm{Br} J$ Cancer 2006, 94(4):552-560.

38. Anandanadesan R, Gong Q, Chipitsyna G, Witkiewicz A, Yeo CJ, Arafat HA: Angiotensin II induces vascular endothelial growth factor in pancreatic cancer cells through an angiotensin II type 1 receptor and ERK $1 / 2$ signaling. J Gastrointest Surg 2008, 12(1):57-66.

39. Fujimoto Y, Sasaki T, Tsuchida A, Chayama K: Angiotensin II type 1 receptor expression in human pancreatic cancer and growth inhibition by angiotensin II type 1 receptor antagonist. FEBS Lett 2001, 495(3):197-200.

40. Ino K, Shibata K, Kajiyama H, Nawa A, Nomura S, Kikkawa F: Manipulating the angiotensin system-new approaches to the treatment of solid tumours. Expert Opin Biol Ther 2006, 6(3):243-255.

41. Stoll M, Steckelings UM, Paul M, Bottari SP, Metzger R, Unger T: The angiotensin AT2-receptor mediates inhibition of cell proliferation in coronary endothelial cells. J Clin Invest 1995, 95(2):651-657.

42. Munzenmaier DH, Greene AS: Opposing actions of angiotensin II on microvascular growth and arterial blood pressure. Hypertension 1996, 27(3 Pt 2):760-765.

43. Hanahan D, Weinberg RA: The hallmarks of cancer. Cell 2000, 100(1):57-70.

44. Hwang RF, Moore T, Arumugam $T$, Ramachandran V, Amos KD, Rivera A, Ji B, Evans DB, Logsdon CD: Cancer-associated stromal fibroblasts promote pancreatic tumor progression. Cancer Res 2008, 68(3):918-926.

45. Sugimoto T, Takiguchi Y, Kurosu K, Kasahara Y, Tanabe N, Tatsumi K, Hiroshima K, Minamihisamatsu M, Miyamoto T, Kuriyama T: Growth factormediated interaction between tumor cells and stromal fibroblasts in an experimental model of human small-cell lung cancer. Oncology Report 2005, 14:823-830.

46. Rosendorff C: The renin-angiotensin system and vascular hypertrophy. J Am Coll Cardiol 1996, 28(4):803-812.

47. Wolf G, Harendza S, Schroeder R, Wenzel U, Zahner G, Butzmann U, Freeman RS, Stahl RA: Angiotensin II's antiproliferative effects mediated through AT2-receptors depend on down-regulation of SM-20. Lab Invest 2002, 82:1305-1317.

48. Carnovali M: The role of the selective blocking of angiotensin II receptors in the treatment of cardiovascular diseases. Clin Ter 2001, 152(2):103-106. 
49. Miura S, Karnik SS: Ligand-independent signals from angiotensin II type 2 receptor induce apoptosis. Embo J 2000, 19(15):4026-4035.

50. Wolf G, Harendza S, Schroeder R, Wenzel U, Zahner G, Butzmann U,

Freeman RS, Stahl RA: Angiotensin II's antiproliferative effects mediated through AT2-receptors depend on down-regulation of SM-20. Lab Invest 2002, 82(10):1305-1317.

51. Xoriuchi M, Hamai M, Cui TX, Iwai M, Minokoshi Y: Cross talk between angiotensin II type 1 and type 2 receptors: cellular mechanism of angiotensin type 2 receptor-mediated cell growth inhibition. Hypertens Res 1999, 22(2):67-74.

\section{Pre-publication history}

The pre-publication history for this paper can be accessed here:http://www. biomedcentral.com/1471-2407/10/67/prepub

doi:10.1186/1471-2407-10-67

Cite this article as: Doi et al.: Angiotensin II type 2 receptor signaling significantly attenuates growth of murine pancreatic carcinoma grafts in syngeneic mice. BMC Cancer 2010 10:67.

\section{Submit your next manuscript to BioMed Central} and take full advantage of:

- Convenient online submission

- Thorough peer review

- No space constraints or color figure charges

- Immediate publication on acceptance

- Inclusion in PubMed, CAS, Scopus and Google Scholar

- Research which is freely available for redistribution

Submit your manuscript at www.biomedcentral.com/submit 